\title{
HUBUNGAN PERSEPSI PETANI TERHADAP PEMBENTUKAN KELOMPOK TANI DENGAN MINAT BERKELOMPOK
}

\section{RELATIONSHIP OF FARMERS PERCEPTION TO THE FORMATION OF FARMERS WITH GROUP INTERESTS}

\author{
Dede Aulia Rahma*1, Suyudi ${ }^{2}$, Hendar Nuryaman ${ }^{3}$ \\ ${ }^{1}$ Mahasiswa Fakultas Pertanian, Universitas Siliwangi \\ ${ }^{2}$ Dosen Fakultas Pertanian Universitas Siliwangi \\ ${ }^{3}$ Dosen Fakultas Pertanian Universitas Siliwangi \\ *E-mail corresponding: dedeauliarahma4@gmail.com
}

\begin{abstract}
ABSTRAK
Penguatan kelembagaan petani dengan membentuk kelompok tani menjadi salah satu solusi untuk mengatasi permasalahan yang ada dalam upaya pengembangan usaha tambak udang vaname. Penelitian ini bertujuan untuk mengetahui persepsi petani tambak udang vaname terhadap pembentukan kelompok tani, minat berkelompok petani tambak udang vaname, dan hubungan persepsi petani terhadap pembentukan kelompok tani dengan minat berkelompok. Metode penelitian menggunakan survei dengan penentuan responden secara sensus terhadap 11 petani tambak udang vaname di Desa Ciandum Kecamatan Cipatujah Kabupaten Tasikmalaya. Untuk persepsi terhadap pembentukkan kelompok tani dan minat berkelompok dianalisis secara deskriptif kuantitatif. Sedangkan untuk hubungan antara persepsi dengan minat digunakan uji korelasi Rank Spearman. Hasil penelitian menunjukkan bahwa persepsi petani tambak udang terhadap pembentukan kelompok tani termasuk kategori persepsi baik. Minat petani tambak udang untuk berkelompok termasuk kategori berminat. Hasil analisis hubungan menunjukkan bahwa persepsi petani tambak udang vaname terhadap pembentukan kelompok tani sangat berhubungan dengan minat berkelompok dengan derajat keeratan sebesar 0,765 yang termasuk kategori kuat.
\end{abstract}

Kata kunci : persepsi,minat, petani tambak udang vaname

\begin{abstract}
Strengthening farmer institutions by forming farmer groups are one solution to overcome the existing problems in the effort to develop vannamei shrimp ponds. This study aims to determine the perceptions of vannamei shrimp farmers on the formation of farmer groups, interest in groups of vannamei shrimp farmers, and the relationship between farmers' perceptions of the formation of farmer groups and group interests. The research method used a survey by determining respondents by the census to 11 farmers of vannamei shrimp in Ciandum Village, Cipatujah District, Tasikmalaya Regency. Perceptions of the formation of farmer groups and interest groups were analyzed descriptively quantitatively. Meanwhile, the correlation between perception and interest was used in the Rank Spearman correlation test. The results showed that the perception of shrimp farmers towards the formation of farmer groups was in the category of good perception. Shrimp farming farmers' interest in groups is included in the interesting category. The results of the relationship analysis show that the perception of the vaname shrimp farmers on the formation of farmer groups is closely related to group interest with a degree of closeness of 0.765 which is in the strong category.
\end{abstract}

Keywords : perception, interest, vaname shrimp pond farmers 


\section{HUBUNGAN PERSEPSI PETANI TERHADAP PEMBENTUKAN KELOMPOK TANI DENGAN MINAT BERKELOMPOK}

Dede Aulia Rahma, Suyudi, Hendar Nuryaman

\section{PENDAHULUAN}

Kabupaten Tasikmalaya merupakan salah satu daerah di Jawa Barat yang memiliki potensi pengembangan subsektor perikanan, baik perikanan tangkap maupun budidaya. Wilayah ini memiliki potensi perikanan yang sangat besar dengan 3 Kecamatan yang memiliki wilayah pesisir dan lautan yang cukup luas yaitu Cikalong, Cipatujah, dan Karangnunggal.

Komoditas kelautan yang menjadi komoditas unggulan Kabupaten Tasikmalaya, yaitu jenis udang vaname. Berdasarkan data yang diperoleh, setiap tahun produksi udang vaname mengalami peningkatan terutama pada tahun 2018, produksi mencapai hingga 1.999,80 ton.

Tabel 1. Data Produksi Udang Vaname di Kabupaten Tasikmalaya

\begin{tabular}{cr}
\hline Tahun & Produksi (Ton) \\
\hline 2014 & 43,15 \\
2015 & 290 \\
2016 & 443,81 \\
2017 & 478,78 \\
2018 & $1.999,80$ \\
2019 & $1.671,70$ \\
\hline
\end{tabular}

Sumber: Dinas Peternakan, Perikanan, dan Kelautan Kabupaten Tasikmalaya, 2019.

Desa Ciandum merupakan salah satu desa yang memiliki potensi besar dalam pengembangan usaha tambak udang vaname. Namun, dibalik potensi besar tersebut terdapat beberapa masalah yang dialami oleh petambak dalam menjalankan usahanya, di antaranya sulit mendapatkan pinjaman modal, kurang adanya pemberdayaan dan pembinaan yang diberikan kepada petambak baik dalam manajemen operasional maupun teknis budidaya, mulai dari pemeliharaan hingga penanganan pasca panen, tidak terjalin komunikasi dan kerja sama yang baik antar petambak udang atau dengan kata lain para petambak melakukan usahanya secara mandiri dan masingmasing, sehingga dirasa sulit bagi petambak untuk memecahkan masalah yang dirasakan.
Mengingat fenomena permasalahan yang terjadi pada petambak, maka dirasa perlu dibentuk kelompok tani yang berfokus pada komoditas udang vaname. Untuk mendukung keberhasilan pembentukan dan efisiensi kinerja kelompok tani dalam menjalankan fungsinya, perlu diketahui bagaimana persepsi dan minat petani tambak udang Desa Ciandum terhadap kelompok tani yang akan dibentuk, serta hubungan keduanya. Dari latar belakang inilah peneliti tertarik untuk melakukan penelitian dengan judul "Hubungan Persepsi Petani terhadap Pembentukan Kelompok Tani dengan Minat Berkelompok".

\section{TINJAUAN PUSTAKA}

\section{Persepsi}

Jalaluddin Rakhmat (2004), "persepsi adalah pengalaman tentang 
objek, atau hubungan yang diperoleh dengan menyimpulkan informasi dan menafsirkan pesan. Persepsi adalah proses kognitif yang memungkinkan kita menginterpretasikan dan memahami sekitar kita. Dikatakan pula sebagai proses menginterpretasikan suatu lingkungan".

Menurut Bimo Walgito (2003) indikator-indikator dalam persepsi antara lain: penyerapan terhadap rangsangan atau objek dari luar individu, pengertian atau pemahaman, dan penilaian atau evaluasi. Hal ini diperkuat oleh pendapat Soekidjo Notoadmojo (2010) bahwa faktor yang mempengaruhi terbentuknya persepsi adalah perhatian, harapan, kebutuhan, ciri kepribadian dan sistem nilai. Berdasarkan pengertian di atas, maka dalam penelitian ini indikator yang digunakan untuk menilai persepsi yaitu pemahaman, tanggapan dan harapan.

\section{Minat}

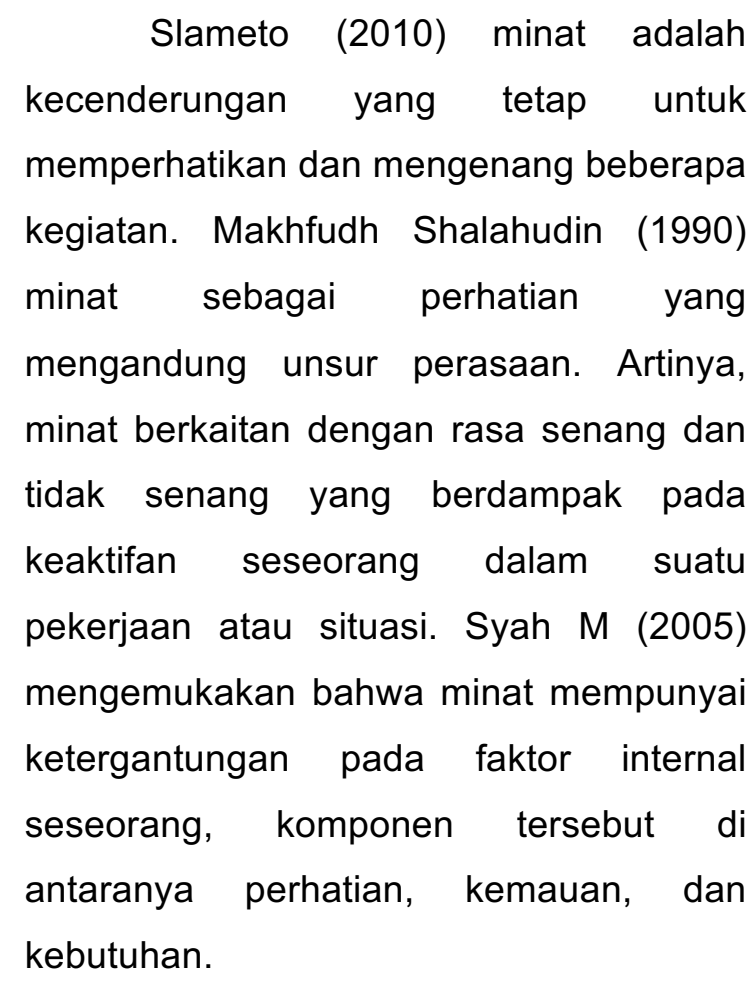

Slameto (2010) minat adalah kecenderungan yang tetap untuk memperhatikan dan mengenang beberapa minat sebagai perhatian yang mengandung unsur perasaan. Artinya, minat berkaitan dengan rasa senang dan tidak senang yang berdampak pada keaktifan seseorang dalam suatu pekerjaan atau situasi. Syah M (2005) mengemukakan bahwa minat mempunyai ketergantungan pada faktor internal kebutuhan

\section{Kelompok Tani}

K. Nainggolan, I.M. Harahap, dan Erdiman (2014) mengatakan bahwa kelompok tani merupakan kumpulan petani yang terikat secara non formal dan dibentuk atas dasar kesamaan kepentingan, kesamaan kondisi lingkungan (sosial, ekonomi, sumber daya), keakraban dan keserasian, serta mempunyai pimpinan untuk mencapai tujuan yang sama. Tujuan dibentuknya kelompok tani adalah meningkatkan dan mengembangkan kemampuan petani dan keluarganya sebagai subjek pendekatan kelompok, agar lebih berperan dalam pembangunan.

\section{METODE PENELITIAN}

Metode penelitian yang digunakan dalam penelitian ini adalah survei dengan penentuan lokasi secara sengaja (purposive). Teknik pengambilan sampel menggunakan sampling jenuh. Teknik ini dilakukan bila jumlah populasi relatif kecil, kurang dari 30 orang, atau penelitian yang ingin membuat generalisasi dengan kesalahan yang sangat kecil (Sugiyono, 2013) .

Jenis dan teknik pengambilan data yang digunakan yaitu data primer yang diperoleh dari hasil wawancara langsung dan data sekunder dari literatur-literatur studi pustaka atau hasil dokumentasi atau publikasi dari instansi terkait yang berhubungan dengan penelitian yang dilakukan. 


\section{HUBUNGAN PERSEPSI PETANI TERHADAP PEMBENTUKAN KELOMPOK TANI DENGAN MINAT BERKELOMPOK}

Dede Aulia Rahma, Suyudi, Hendar Nuryaman

\section{Analisis Deskriptif}

Penelitian deskriptif dalam penelitian ini dimaksudkan untuk memperoleh gambaran dan keterangan mengenai persepsi tentang pembentukan kelompok tani dan minat petani tambak udang untuk berkelompok. Skala pengukuran yang digunakan yaitu skala Likert, skala yang didasarkan pada penjumlahan sikap responden dalam merespon pernyataan berkaitan dengan indikator atau variabel yang diukur (Anwar Sanusi, 2011). Pengukuran setiap indikator pada setiap variabel ditentukan dengan menggunakan batas kategori yang digambarkan ke dalam garis kontinum.

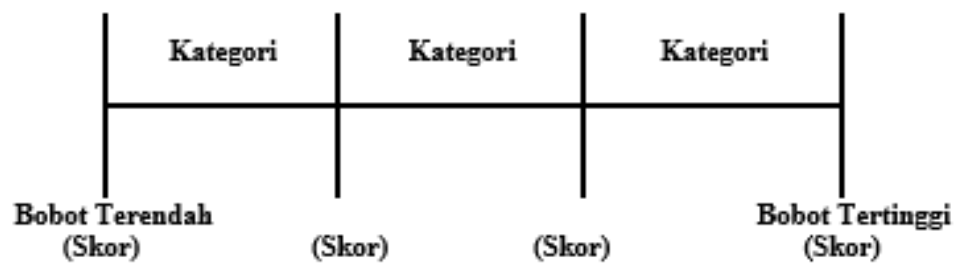

Gambar 1. Garis Kontinum

Selanjutnya, data dianalisis dengan menggunakan Nilai Tertimbang (NT). Nilai tertimbang merupakan persentasi nilai yang berasal dari pengukuran-pengukuran indikator atau variabel, dengan menggunakan rumus Djoni (2008) sebagai berikut:

NT $=\frac{\text { Nilai yang didapat }}{\text { Nilai Ideal } / \text { maksimal }} \times 100 \%$

\section{Uji Validitas dan Reliabilitas}

Uji validitas merupakan uji yang digunakan untuk mengetahui seberapa cermat suatu alat ukur dalam melakukan fungsi ukurannya. Uji validitas instrumen dilakukan dengan menggunakan teknik korelasi product moment. Uji reliabilitas merupakan uji yang digunakan untuk mengetahui konsistensi dari instrumen sebagai alat ukur, sehingga suatu pengukuran dapat dipercaya. Teknik pengukuran reliabilitas yang digunakan adalah teknik Cronbach's Alpha.

\section{Uji Korelasi}

Analisis hubungan antara persepsi terhadap pembentukan kelompok tani dan minat berkelompok petani tambak udang vaname dapat diketahui dengan menggunakan uji statistik Rank Spearman (Sugiyono, 2013).

Untuk membuktikan hubungan dari variabel persepsi petani terhadap pembentukan kelompok tani dengan minat berkelompok. dalam penelitian ini adalah: $\mathrm{H}_{0}: \rho s \neq 0$ : Tidak terdapat hubungan antara persepsi terhadap pembentukan kelompok tani dengan minat berkelompok.

$\mathrm{H}_{1}$ : $\rho s=0$ : Terdapat hubungan antara persepsi terhadap pembentukan kelompok tani dengan minat berkelompok. 
HASIL DAN PEMBAHASAN

\section{Karakteristik Petani Tambak Udang Vaname}

Petani tambak udang di Desa Ciandum merupakan petani yang seluruhnya berada pada usia produktif, yaitu rentang usia 15 - 64 tahun. Petani pun memiliki tingkat pendidikan yang cukup tinggi, karena sebagian besar petani sudah menempuh pendidikan menengah dan pendidikan tinggi. Namun, petani belum memiliki pengalaman yang cukup dalam berusaha tambak udang vaname. Hal ini disebabkan karena pengembangan usaha perikanan komoditas udang vaname di Desa Ciandum masih tergolong baru. Sehingga pengalaman dan pengetahuan mereka mengenai usaha tambak udang masih rendah. Adapun luas lahan yang dimiliki petani tambak udang di Desa Ciandum sebagian besar memiliki lahan usaha yang sempit.

\section{Persepsi Petani Tambak Udang terhadap Pembentukan Kelompok Tani}

Dalam penelitian yang dilakukan indikator persepsi yang digunakan yaitu, pemahaman, tanggapan dan harapan.

\section{Pemahaman}

Pemahaman menurut Benjamin S. Bloom dalam Anas Sudijono (2006) adalah kemampuan untuk mengerti atau memahami sesuatu setelah sesuatu itu diketahui dan diingat. Dalam penelitian yang dilakukan terkait pemahaman petani tambak udang ditujukan pada pemahaman mengenai tujuan dibentuknya kelompok tani, fungsi kelompok tani, kemudahan akses permodalan, peningkatan kesejahteraan. Perolehan nilai pada indikator pemahaman memiliki skor maksimal atau bobot tertinggi sebesar 132, sementara jumlah perolehan nilai dari jawaban pertanyaan diperoleh nilai sebesar 109 dengan nilai rata-rata tertimbang sebesar 82,57 persen. Dari nilai tersebut, dapat diketahui bahwa petani tambak udang memiliki pemahaman terkait tujuan dibentuknya kelompok tani. Artinya, petani menyadari bahwa adanya kelompok tani adalah untuk meningkatkan dan mengembangkan usaha yang dijalankan. Sesuai dengan pendapat Totok Mardikanto (2009) bahwa tujuan dibentuknya kelompok tani yaitu agar petani dapat menjalankan usaha taninya secara bersama-sama sehingga dapat meningkatkan dan mengembangkan dan mengembangkan usaha tani yang dijalankan oleh anggota dan kelompok. Selanjutnya petani memiliki pemahaman rendah terkait fungsi kelompok tani. Berdasarkan hasil wawancara di lapangan, sebagian besar hanya mengetahui bahwa fungsi kelompok tani adalah sebagai wadah kerja sama antar petani dan sebagai perantara jika ada bantuan dari pemerintah.

Petani pun memiliki pemahaman yang tinggi terkait kelompok tani dapat memudahkan akses permodalan, petani memiliki anggapan bahwa dengan dibentuknya kelompok tani, akan memudahkan petani dalam akses permodalan untuk mempertahankan 


\section{HUBUNGAN PERSEPSI PETANI TERHADAP PEMBENTUKAN KELOMPOK TANI DENGAN MINAT BERKELOMPOK}

Dede Aulia Rahma, Suyudi, Hendar Nuryaman

bahkan mengembangkan usaha tambak udang vaname yang sedang dilakukan.

Pemahaman petani terkait peranan kelompok tani dalam peningkatan kesejahteraan petani tambak udang di Desa Ciandum termasuk kategori tinggi, artinya pemahaman petani tambak udang di Desa Ciandum sudah mengetahui peranan dari kelompok tani.

\section{Tanggapan}

Zulrizka Iskandar

menyatakan bahwa tanggapan merupakan perilaku atau tingkah laku yang terjadi pada manusia setelah ia mendapatkan stimulus atau objek yang ada di lingkungan. Proses terjadinya tanggapan dimulai dengan adanya rangsangan yang diterima kemudian muncul perhatian yang menimbulkan persepsi (Tri Rusmi Widayatun, 1999).

Penelitian yang dilakukan terkait tanggapan petani ditujukan pada tanggapan terhadap kemudahan usaha dilihat dari status pendidikan petani tambak udang vaname, peningkatan usaha, dan manfaat kelompok tani. Perolehan nilai pada indikator tanggapan memiliki skor maksimal atau bobot tertinggi sebesar 99, sementara jumlah perolehan skor dari jawaban pertanyaan sebesar 79 dengan nilai rata-rata tertimbang sebesar 79,80 persen.

Berdasarkan sub indikator kemudahan usaha dilihat dari status pendidikan petani tambak udang vaname, skor yang diperoleh termasuk kategori rendah, hal ini berarti bahwa petani tambak udang tidak memberikan tanggapan yang baik. Tanggapan lain adalah bahwa dengan dibentuknya kelompok tani mereka meyakini adanya peningkatan usaha tambak yang dijalankan serta anggapan bahwa dengan adanya kelompok tani, usaha tambak udang akan lebih terorganisasi, terutama dalam pemasaran hasil produksi, informasi dan teknologi yang efektif.

\section{Harapan}

C.R. Snyder (2000) menyatakan bahwa harapan adalah keseluruhan dari kemampuan yang dimiliki individu untuk menghasilkan jalur mencapai tujuan yang diinginkan. Harapan juga merupakan suatu mental yang positif yang akan meningkatkan kemampuan seorang individu untuk mencapai tujuan di masa yang akan datang. Dalam penelitian yang dilakukan terkait tanggapan petani tambak udang ditujukan pada tanggapan terhadap inovasi untuk efisiensi dan efektivitas usaha tambak, terjalin komunikasi dan kerja sama antar petani, stabilitas harga udang, simpan pinjam, serta pembinaan dan pencerdasan dari agen penyuluh.

Harapan petani terhadap inovasi dalam kelompok tani belum menjadi prioritas karena yang paling diharapkan oleh petani tambak udang adalah komunikasi dan kerja sama yang baik antar petani tambak dan pemerintah. Sementara harapan terhadap terjalinnya kerjasama antar petani termasuk kategori tinggi. 
Sebagian besar para petani menganggap bahwa kerja sama yang baik antar petani sangat memudahkan petani dalam menjalankan usahanya.

Selanjutnya, petani memberikan harapan yang tinggi terhadap adanya stabilitas harga udang yang merupakan salah satu masalah yang dihadapi petambak saat ini. Harapan lain yaitu pada pengadaan simpan pinjam, pembinaan dan pencerdasan dari agen penyuluh kepada petani tambak udang di Desa Ciandum. Perolehan skor pada harapan adanya pengadaan simpan pinjam termasuk pada kategori tinggi. pada harapan adanya pembinaan dan pencerdasan. Skor didapat dari tingginya harapan petani untuk mendapatkan bantuan modal usaha serta adanya agen yang dapat membina mereka.

Penelitian yang dilakukan pada petani tambak udang di Desa Ciandum menunjukkan hasil bahwa berdasarkan indikator pemahaman, tanggapan, dan harapan petani memiliki persepsi baik terhadap pembentukan kelompok tani. Tabel 2 berikut menunjukkan hasil bahwa petani tambak udang vaname di Desa Ciandum memiliki persepsi baik terhadap pembentukan kelompok tani.

Tabel 2 Persepsi Petani Tambak Udang terhadap Pembentukan Kelompok Tani

\begin{tabular}{lllll}
\hline No & Indikator & Skor yang Dicapai & Skor Maksimal & Kategori \\
\hline 1 & Pemahaman & 109 & 132 & Faham \\
2 & Tanggapan & 79 & 99 & Baik \\
3 & Harapan & 136 & 165 & Sesuai \\
\hline Total & $\mathbf{3 2 4}$ & $\mathbf{3 9 6}$ & Persepsi Baik \\
\hline
\end{tabular}

Sumber: Data Primer Diolah 2020

\section{Minat Berkelompok Petani Tambak Udang}

Dalam penelitian yang dilakukan indikator minat yang digunakan yaitu, perhatian, kemauan dan kebutuhan.

\section{Perhatian}

Perhatian menurut $\begin{array}{r}\text { Sumadi } \\ \text { Suryabrata (2010) adalah banyak }\end{array}$
sedikitnya kesadaran yang menyertai
sesuatu aktivitas yang dilakukan. Perhatian
juga merupakan pemusatan tenaga atau
kekuatan jiwa tertentu kepada suatu obyek,
atau pendayagunaan kesadaran untuk
menyertai suatu aktivitas.

Berdasarkan indikator perhatian, petani memberikan skor tinggi terhadap item usaha secara berkelompok. Hal ini berarti bahwa petani memberikan perhatian yang tinggi terhadap minat mereka dalam berkelompok. Sebagian besar petani tambak udang mengatakan bahwa mereka menyukai jika berusaha secara berkelompok, karena menurut mereka dengan berkelompok maka usaha akan lebih kuat, tidak hanya dalam kerja sama saling meningkatkan usaha tetapi juga kontinuitas usaha pun akan terbentuk dengan baik, selain itu hubungan petani akan semakin terjalin dengan baik. 


\section{HUBUNGAN PERSEPSI PETANI TERHADAP PEMBENTUKAN KELOMPOK TANI DENGAN MINAT BERKELOMPOK}

Dede Aulia Rahma, Suyudi, Hendar Nuryaman

Perhatian yang tinggi terhadap usaha secara berkelompok yang diberikan oleh petani tentu saja didukung oleh perhatian mereka terhadap kemudahan usaha dengan cara berkelompok, artinya bahwa petani berminat bergabung dengan kelompok tani karena adanya manfaat yang dirasa dapat memudahkan mereka dalam menjalankan usaha tambak. Petani mengatakan bahwa tujuan mereka bergabung dengan kelompok tani adalah tidak lain untuk mendapatkan kemudahan dalam berkelompok.

Selanjutnya, petani tambak udang memberikan skor tinggi terhadap peningkatan keterampilan, artinya petani merasa jika bergabung dengan kelompok tani, keterampilan mereka dalam menjalankan usaha akan semakin meningkat. Petani juga berharap dengan bergabungnya mereka dengan kelompok tani, akan ada pembinaan, pelatihan atau wadah konsultasi yang dapat memberikan pengetahuan dan wawasan mereka dalam budidaya udang vaname, sehingga keterampilan mereka akan meningkat, baik keterampilan dalam manajemen usaha budidaya udang maupun penanggulangan risiko yang ada pada usaha tambak udang.

\section{Kemauan}

Kemauan merupakan salah satu fungsi hidup kejiwaan manusia yang mengandung usaha aktif dan berhubungan dengan pelaksanaan sesuatu tujuan, kemauan bisa disamakan dengan kehendak atau hasrat. Kemauan dipengaruhi oleh keadaan dalam diri dan lingkungan. Dengan modal kemauan yang kuat orang dapat memilih jalan yang sebaik-baiknya untuk dilalui (Abu Ahmadi, 2013).

Berdasarkan perhitungan, dapat diketahui bahwa dari indikator kemauan, secara garis besar petani memiliki cukup kemauan untuk bergabung dengan kelompok tani. Namun, pada item kemauan untuk aktif berdiskusi jika petani tambak udang bergabung dengan kelompok tani memiliki skor sedang. Berdasarkan wawancara di lapangan, petani merasa ragu dengan pernyataan ini, karena mereka berpendapat bahwa mereka akan aktif berdiskusi jika pendapat atau gagasan mereka dibutuhkan dalam pertemuan kelompok tani.

Kemauan petani untuk hadir di setiap pertemuan anggota mendapatkan skor dengan kategori tinggi,. Yang berarti bahwa sebagian besar petani tambak udang di Desa Ciandum bersedia untuk menghadiri pertemuan atau rapat yang diselenggarakan oleh kelompok tani. Namun, tidak semua petani memberikan tanggapan baik, sebanyak 9,09 petani tidak mau untuk menghadiri pertemuan anggota kelompok tani, alasannya karena petani tersebut tidak fokus terhadap usaha tambak saja, petani memiliki banyak usaha di bidang lainnya, akibatnya banyak aktivitas yang harus dilakukan dan menjadi prioritas selain tambak udang. Hal lain yang mendorong minat petani tambak 
udang untuk berkelompok yaitu mereka bersedia untuk diberi jabatan dan mengikuti aturan dalam kelompok tanisebanyak 63,64 persen petani termasuk kategori mau untuk menjabat dan mengikuti aturan dalam kelompok, karena mereka menilai aturan dalam suatu organisasi penting agar anggota dapat melakukan tugas dan fungsinya dengan baik dan terarah.

\section{Kebutuhan}

Kebutuhan atau needs adalah kekuatan yang diarahkan pada pencapaian tujuan yang dialami orang. Kebutuhan juga merupakan kekuatan motivasi emosional dihubungkan pada tujuan tertentu untuk mengoreksi kekurangan (Wibowo, 2013).

didapat dari hasil analisis termasuk kategori tinggi Sebagian besar petani mengatakan bahwa ketertarikan mereka untuk berkelompok tani salah satunya memperluas jaringan pemasaran. Hal ini berkaitan dengan fungsi kelompok tani yaitu sebagai unit produksi, yang berarti usaha tani masing-masing anggota kelompok secara keseluruhan merupakan satu kesatuan usaha yang dapat dikembangkan untuk mencapai skala ekonomi usaha, dengan menjaga kuantitas, kualitas, dan kontinuitas (Peraturan Menteri Pertanian, 2016).

Dorongan petani untuk bergabung dengan kelompok tani pun didukung oleh kebutuhan mereka akan adanya wadah konsultasi. Hal ini dapat diketahui dari skor
Berdasarkan indikator kebutuhan dapat diketahui bahwa petani tambak udang memiliki kebutuhan yang tinggi terhadap peningkatan usaha tambak udang dan memecahkan masalah secara bersama. Hal ini membuktikan bahwa sebagian besar petani merasakan adanya kebutuhan terhadap peningkatan usaha dan kerja sama antar petani dalam memecahkan masalah, karena petani tambak akan kesulitan jika mereka bekerjasecara mandiri atau tanpa adanya sosialisasi dari petani tambak lain.

Hal lain yang mendorong petani memiliki minat untuk berkelompok tani adalah adanya kebutuhan untuk memperluas jaringan pemasaran. Skor yang

yang didapat termasuk kategori tinggi yaitu sebesar 90,91 persen. Kebutuhan pada item tersebut lebih mendominasi dari item kebutuhan yang lain. Angka tersebut menunjukkan bahwa saat ini wadah konsultasi sangat dibutuhkan oleh petani, hal ini terkait terbatasnya pemahaman dan pengalaman petani terhadap usaha yang dijalankan. Wadah konsultasi ini tentu saja harus melibatkan agen yang ahli dalam bidang tersebut.

Penelitian yang dilakukan pada petani tambak udang di Desa Ciandum menunjukkan bahwa petani tambak udang di Desa Ciandum berminat untuk berkelompok tani. Lebih jelasnya dapat dilihat dari Tabel berikut. 
HUBUNGAN PERSEPSI PETANI TERHADAP PEMBENTUKAN KELOMPOK TANI DENGAN MINAT BERKELOMPOK

Dede Aulia Rahma, Suyudi, Hendar Nuryaman

Tabel 3 Minat Berkelompok Petani Tambak Udang di Desa Ciandum

\begin{tabular}{lllll}
\hline No & Indikator & Skor yang Dicapai & $\begin{array}{l}\text { Skor } \\
\text { Maksimal }\end{array}$ & Kategori \\
\hline 1 & Perhatian & 82 & 99 & Tinggi \\
2 & Kemauan & 81 & 99 & Mau \\
3 & Kebutuhan & 115 & 132 & Butuh \\
\hline Total & & $\mathbf{2 7 8}$ & $\mathbf{3 3 0}$ & Berminat \\
\hline
\end{tabular}

Sumber: Data Primer Diolah 2020

Hubungan antara Persepsi Terhadap Pembentukan Kelompok Tani dengan Minat Berkelompok

Hubungan antara persepsi terhadap pembentukan kelompok tani dengan minat berkelompok diperoleh dengan menggunakan analisis Rank Spearman. Hasil perhitungan dapat dilihat pada tabel hasil uji yang dilakukan dengan Rank Spearman dapat diketahui bahwa hubungan antara persepsi terhadap pembentukan kelompok tani dengan minat berkelompok petani tambak udang di Desa
Ciandum sebesar 0,765 dengan signifikansi 0,006.

Hasil uji Jika nilai tersebut diinterpretasikan maka dapat diketahui bahwa terdapat hubungan antara persepsi terhadap pembentukan kelompok tani dengan minat berkelompok petani tambak udang vaname di Desa Ciandum Kec.Cipatujah. Persepsi dan minat memiliki hubungan yang sangat signifikan.

Dapat dilihat di Tabel 4 berikut.

Tabel 4. Korelasi antara Persepsi terhadap Pembentukan Kelompok Tani dengan Minat Berkelompok Correlations

\begin{tabular}{|c|c|c|c|c|}
\hline & & & persepsi & Minat \\
\hline \multirow[t]{6}{*}{ Spearman's rho } & persepsi & Correlation Coefficient & 1,000 &, $765^{* *}$ \\
\hline & & Sig. (2-tailed) & & ,006 \\
\hline & & $\mathrm{N}$ & 11 & 11 \\
\hline & Minat & Correlation Coefficient &, $765^{* *}$ & 1,000 \\
\hline & & Sig. (2-tailed) & ,006 & . \\
\hline & & $\mathrm{N}$ & 11 & 11 \\
\hline
\end{tabular}

**. Correlation is significant at the 0.01 level (2-tailed). 
Minat individu sangat dipengaruhi oleh persepsi individu yang bersangkutan, karena dengan persepsi individu dapat menyadari dan mengerti tentang keadaan lingkungannya serta keadaan diri individu yang bersangkutan. Sehingga dengan begitu individu dapat memutuskan perilaku atau reaksi apa yang harus dilakukannya dalam hal ini berupa minat. Hal ini sejalan dengan Jogiyanto (2007) yaitu minat berhubungan dengan norma subjektif yakni persepsi atau pandangan seseorang terhadap tekanan sosial yang akan mempengaruhi minat untuk melakukan atau tidak melakukan perilaku yang sedang dipertimbangkan.

\section{KESIMPULAN}

1. Persepsi petani tambak udang terhadap pembentukan kelompok tani secara keseluruhan termasuk kategori baik, dengan pemahaman petani yang termasuk kategori faham, tanggapan yang termasuk kategori baik, dan harapan petani yang termasuk kategori sesuai. Hal ini berarti petani mendukung adanya pembentukan kelompok tani petani tambak udang vaname di Desa Ciandum Kec. Cipatujah.

2. Minat petani tambak udang untuk berkelompok secara keseluruhan termasuk kategori berminat, dengan perhatian termasuk kategori tinggi, serta kemauan termasuk kategori mau, dan kebutuhan termasuk kategori butuh.

3. Hasil analisis hubungan menunjukkan bahwa persepsi petani tambak udang vaname terhadap pembentukan kelompok tani sangat berhubungan dengan minat berkelompok.

\section{DAFTAR PUSTAKA}

Abu Ahmadi. 2013. Psikolog Belajar. Rineka Cipta, Jakarta.

Anas Sudijono. 2006. Pengantar Evaluasi Pendidikan. PT Raja Grafindo Persada, Jakarta

Anwar Sanusi. 2011. Metode Penelitian Bisnis. Jakarta: Salemba Empat.

Bimo Walgito. 2003. Pengantar Psikologi Umum. Edisi 4. Andi, Yogyakarta.

C.R. Snyder. 2000. Handbook of Hope: Theory, Measures \& Applications. New York: Igded Maternad.

Dinas Peternakan, perikanan, dan kelautan. 2019. Produksi Udang Vaname Kabupaten Tasikmalaya.

Djoni. 2008. Metode Penelitian Sosial Ekonomi. Program Pascasarjana Universitas Siliwangi, Tasikmalaya. Jalaluddin Rakhmat. 2004. Psikologi Komunikasi. PT. Remaja Rosdakarya, Bandung.

Jogiyanto. 2007. Sistem Informasi Keperilakuan. Andi, Yogyakarta

K. Nainggolan, I.M. Harahap, dan Erdiman. 2014. Teknologi Melipat Gandakan Produksi Padi Nasional. PT Gramedua Widiasarana Indonesia, Jakarta.

Makhfudh Shalahudin. 1990. Pengantar Psikologi Pendidikan. Bina IImu, Surabaya.

Departemen Pertanian. 2016. Peraturan Menteri Pertanian No.67/Permentan /SM.050/12/2016 Tentang Pembinaan Kelembagaan Petani. Departemen Pertanian. Jakarta. 
Slameto. 2010. Belajar dan Faktor-Faktor yang Mempengaruhinya. Rineka Cipta, Jakarta.

Soekidjo Notoadmojo. 2010. IImu Perilaku Kesehatan. Rineka Cipta, Jakarta.

Sugiyono. 2013. Metode Penelitian Pendidikan Pendekatan Kuantitatif, Kualitatif, dan R\&D. Alfabeta, Bandung.

Sumadi Suryabrata. 2014. Psikologi Pendidikan. Rajawali: Jakarta.
Syah M. 2005. Psikologi Belajar. PT. Raja Grafindo Persada, Jakarta.

Totok Mardikanto. 2009. Sistem Penyuluhan Pertanian. Universitas Sebelas Maret. Surakarta.

Tri Rusmi Widayatun. 1999. IImu Prilaku. Sagung Seto, Jakarta.

Wibowo. 2013.Perilaku dalam Organisasi (ed.I cet.I). Rajawali Pers. Jakarta.

Zulrizka Iskandar. 2012. Psikologi Lingkungan Teori dan Konsep. PT. Refika Aditama, Bandung. 